\title{
GAMBARAN DUKUNGAN KELUARGA DALAM PELAKSANAAN PERAWATAN METODE KANGURU PADA IBU MUDA YANG MEMILIKI BAYI BERAT LAHIR RENDAH (BBLR) DI UPTD RSUD KABUPATEN INDRAMAYU
}

\author{
Eleni Kenanga Purbasary \\ Dosen Program Studi Sarjana Keperawatan STIKes Indramayu \\ Email : ellen_sary@yahoo.com
}

\section{ABSTRAK}

Perawatan Merode Kanguru (PMK) adalah perawatan cara alami untuk bayi prematur dan BBLR didasarkan pada kontak kulit ke kulit antara bayi dan ibu dalam posisi tegak berhadapan dengan ibu. Tujuan penelitian ini yaitu untuk mengetahui gambaran dukungan keluarga dalam pelaksanaan PMK pada ibu muda yang memiliki BBLR. Penelitian ini merupakan penelitian kuantitatif dengan pendekatan deskriptif analitik. Pengambilan sampel dalam penelitian ini dengan teknik consecutive sampling, dengan sampel 26 responden. Analisa yang digunakan adalah analisa univariat. Hasil penelitian ini rata-rata (mean) usia ibu 22,5, ibu dengan pendidikan dasar sebanyak 17 orang $(65,39 \%)$, dan sebanyak $24 \mathrm{Ibu}(92,30 \%)$ mendapatkan dukungan keluarga dalam melakukan PMK, serta 24 ibu belum memiliki pengalaman dalam melahirkan. Kesimpulan dalam penelitian ini adalah ibu muda yang memiliki BBLR lebih banyak mendapatkan dukungan keluarga dalam pelaksanaan PMK. Hasil penelitian ini diharapkan kepada petugas kesehatan untuk dapat meningkatkan penyuluhan kesehatan tentang PMK kepada ibu hamil, sehingga ibu yang memiliki risiko bayi dengan BBLR dapat mengetahui dan melakukan PMK dengan cara yang benar pada saat bayi sudah diperbolehkan PMK.

Kata Kunci: Bayi Berat Lahir Rendah, Dukungan keluarga, Perawatan Metode Kanguru

\section{PENDAHULUAN}

Bayi Berat Lahir Rendah adalah bayi yang lahir dengan berat badan $<2500$ gram tanpa melihat usia kehamilan (Proverawati \& Ismawati, 2010). Berat lahir adalah berat badan bayi dalam 1 jam pertama kelahiran jika dilahirkan di pelayanan kesehatan (puskesmas, polindes, dan rumah sakit), atau berat badan bayi yang di timbang dalam 24 jam pertama kelahiran jika bayi dilahirkan di rumah (Departemen Kesehatan Republik Indonesia, 2010).

Angka kematian bayi (AKB) di Indonesia (0-12 bulan) masih tinggi berkisar 32/1000 kelahiran hidup dan penyumbang terbesar adalah kematian pada bayi baru lahir (neonatus) (Badan Pusat Statistik, 2013). Riskesdas (2013) prevalensi balita (0-59 bulan) dengan bayi berat lahir rendah (BBLR) sebesar $\quad 10,2 \%$ terjadi penurunan dibandingkan hasil Riskesdas 2010 yang mencapai angka $11,1 \%$. Provinsi Sulawesi Tengah memiliki persentase BBLR tertinggi $(16,8 \%)$, dan provinsi Sumatera Utara terendah $(7,2 \%)$, sedangkan provinsi Jawa Barat presentase BBLR sebesar 10,8\%
(Kementerian Kesehatan Republik Indonesia, 2014).

Angka kematian bayi (0-11bulan) di Provinsi Jawa Barat tahun 2016 berjumlah 3.647 kasus dengan wilayah kabupaten Garut di urutan pertama sebesar $(9,21 \%)$, diikuti kabupaten Indramayu sebesar $(8,82 \%)$, dan kabupaten Sukabumi sebesar (8,71\%). Penyebab sebagian besar kematian bayi, terjadi pada masa neonatal, dan 54,64\% diakibatkan oleh BBLR, asfiksia, dan sepsis (Dinas Kesehatan Indramayu, 2016).

Berbagai program sudah dilakukan untuk mengurangi angka kematian bayi, diantaranya: Kementerian Kesehatan Republik Indonesia bekerjasama dengan United States Agency for International Development (USAID) selama lima tahun (2012-2016) dalam program Expanding Maternal And Neonatal Survival (EMAS) di Provinsi Jawa Barat. Program EMAS ini mempunyai tujuan menurunkan angka kematian ibu dan bayi baru lahir di Indonesia sebesar 25\%. Program EMAS dilaksanakan di 30 kabupaten dari 6 propinsi, yaitu: Sumatera Utara, Sulawesi Selatan, Banten, Jawa Barat, Jawa Tengah, dan Jawa Timur. Wilayah Jawa Barat sendiri 
terpilih 5 kabupaten, yaitu: Kabupaten Bandung, Cirebon, Karawang, Indramayu, dan Bogor.

Kabupaten Indramayu mendapatkan kesempatan menjalankan progaram EMAS di tahun 2015. Program EMAS berakhir tahun 2016, namun demikian pemerintah kabupaten Indramayu tetap melanjutkan program tersebut untuk menurunkan angka kematian ibu dan anak dengan nama program Selamatkan Bayi dan Ibu Indramayu (SI BAYU). Pemerintah kabupaten Indramayu juga menjalankan program sistem informasi dan komunikasi berbasis teknologi informasi bagi ibu hamil, tenaga kesehatan dalam proses kehamilan, perencanaan, persalinan, pencegahan komplikasi, dan rujukan kegawatdaruratan maternal neonatal yang bertujuan untuk menyelamatkan ibu dan bayi dengan nama Sistem Rujukan Maternal Neonatal Versi Indramayu (SI IRMA AYU).

Rumah Sakit Indramayu memiliki jumlah pasien BBLR sebanyak (16,5\%) dari total 915 BBLR periode Januari-Desember, dimana BBLR merupakan salah satu penyebab kematian tertinggi pada bayi di wilayah kabupaten Indramayu.Hipotermi masih menjadi salah satu masalah yang terjadi pada BBLR di RSUD Indramayu ketika bayi masih dalam perawatan di rumah sakit.

Berbagai upaya dapat dilakukan untuk mencegah terjadinya hipotermi, perawatan metode kanguru (PMK) merupakan salah satu metode pemberian kehangatan pada BBLR. Worku dan Kassie (2005) menyatakan dalam penelitiannya PMK dapat memberikan kelangsungan hidup yang sangat baik pada BBLR, dapat mengurangi tingkat kematian pada BBLR.

Penelitian lain yang dilakukan Seidman et al. (2015) mengatakan hambatan yang terkait sumber daya dalam pelaksanaan PMK, diantaranya: fasilitas yang tersedia dan sumber daya manusia itu sendiri (kesan negatif dari interaksi dengan tenaga kesehatan dan sikap dari staf tersebut), kurangnya bantuan pada pelaksaanan PMK, kesadaran untuk melakukan PMK yang masih rendah, dan kurangnya dukungan dari suami, teman dan keluarga.

Berdasarkan uraian diatas maka peneliti tertarik melakukan penelitian dengan judul "Gambaran dukungan keluarga dalampelaksanaan perawatan metode kangurupada ibu muda yang memiliki bayi berat lahir rendah (BBLR) di UPTD RSUD Kabupaten Indramayu.

\section{METODOLOGI PENELITIAN}

Jenis peneitian ini adalah penelitian kuantitatif dengan pendekatan dektriptif analitik. Populasi penelitian ini adalah semua ibuyang memiliki bayi BBLR di ruang Perinatologi rumah sakit di wilayah Indramayu. Pengambilan sampel dalam penelitian ini menggunakan teknik consecutive sampling, dengan besar sample 26 responden.

\section{HASIL PENELITIAN}

\section{Karakteristik Responden}

Tabel 1 Distribusi frekuensi karakteristik responden berdasarkan rerata Usia responden Ibu

\begin{tabular}{ccccc}
\hline Varibel & Mean & SD & $\begin{array}{c}\text { Min- } \\
\text { Maks }\end{array}$ & 95\% CI \\
\hline Usia Ibu & 22,5 & 2,214 & $18-25$ & $\begin{array}{c}21,61- \\
23,39\end{array}$ \\
\hline
\end{tabular}

Tabel 2 Distribusi frekuensi karakteristik responden berdasarkan pendidikan ibu, pengalaman melahirkan di UPTD RSUD Kabupaten Indramayu

\begin{tabular}{|c|c|c|c|}
\hline $\begin{array}{l}\mathbf{N} \\
\mathbf{0}\end{array}$ & Karakteristik Responden & $\mathbf{F}$ & $\%$ \\
\hline \multicolumn{4}{|c|}{ Pendidikan } \\
\hline 1 & Pendidikan Dasar & 17 & $\begin{array}{c}65,3 \\
9\end{array}$ \\
\hline 2 & Pendidikan Menengah & 9 & $\begin{array}{c}34,6 \\
1\end{array}$ \\
\hline \multicolumn{4}{|c|}{ Pengalaman Melahirkan } \\
\hline 1 & Ada Pengalaman & 2 & 7,70 \\
\hline 2 & Belum Ada Pengalaman & 24 & $\begin{array}{c}92,3 \\
0\end{array}$ \\
\hline JuI & nlah & 26 & 100 \\
\hline
\end{tabular}

2. Analisis Univariat

Tabel 3 Distribusi Frekuensi Dukungan Keluarga Dalam Pelaksanaan PMK di RSUD Kabupaten Indramayu

\begin{tabular}{clcc}
\hline No & Dukungan Keluarga & F & \% \\
\hline 1 & Ada Dukungan & 24 & 92,30 \\
2 & Tidak Ada Dukungan & 2 & 7,70 \\
\hline Jumlah & $\mathbf{2 6}$ & $\mathbf{1 0 0}$ \\
\hline
\end{tabular}




\section{PEMBAHASAN}

\section{Karakteristik Responden}

Berdasarkan hasil penelitian Ibu termuda berusia berusia 18 tahun dan usia tertua 25 tahun. Rentang usia remaja menuju dewasa awal memegang peranan penting dalam hal kematangan emosional dan memiliki tanggung jawab terhadap tindakan, sikap, keinginan yang dimiliki, dan tidak bergantung kepada orang lain (Suntrock, 2012).

UU No. 1 Tahun 1974 pasal 7 tentang perkawinan, mengatakan perkawinan diizinkan bila pihak pria mencapai umur 19 (sembilan belas) tahun dan pihak wanita sudah mencapai usia 16 (enam belas) tahun. Wanita yang menikah di usia 16 tahun disarankan untuk hamil setelah berusia 21 tahun, karena memiliki risiko dan belum tercukupinya kesiapan dalam aspek mental, emosional, kesehatan, sosial ekonomi, pendidikan, dan reproduksi (Kementerian Kesehatan Republik Indonesia, 2016). Menurut Survei Demografi Kesehatan Indonesia (SDKI) (2012) usia yang ideal untuk pernikahan bagi perempuan berkisar antara 24-25 tahun, dimana usia tersebut telah memiliki kematangan fisik dan emosional.

Persalinan pada wanita usia dibawah 21 tahun berkontribusi dalam tingginya angka kematian neonatal dan balita. SDKI (2012) ibu yang melahirkan diusia kurang 21 tahun memiliki kontribusi yang lebih besar dalam peningkatan angka kematian neonatal, post neonatal, bayi, dan balita dibandingkan pada ibu yang melahirkan diusia 21-29 tahun. Ibu yang hamil di usia sebelum 21 tahun masih dalam masa tumbuh kembang, dan tidak mendapatkan perawatan gizi yang maksimal (Kementerian Kesehatan RI, 2016).

Tingkat pendidikan ibu memengaruhi kemampuan dan pemahaman ibu dalam memahami informasi yang diberikan, memengaruhi sikap, dan perilaku ke arah yang baik (Ahmed, Moussa, Petterson, \& Asamoah, 2012; Dusing, Van Drew, \& Brown, 2012). Dalam hal ini pendidikan ibu juga akan memengaruhi kepatuhan ibu dalam melakukan pemeriksaan kehamilan. Ibu yang melakukan pemeriksaan kehamilan yang sesuai dengan jadwal akan menurunkan risiko terjadinya BBLR (Kuo, 2012).

Penelitian Mutmainah (2006) menemukan bahwa pendidikan berhubungan dengan kemampuan merawat bayi. Ibu yang berpendidikan tinggi akan memiliki cara berpikir terbuka ketika mempunyai masalah, dan akan mengungkapkan kesulitannya dalam hal melakukan perawatan bayi (Hockenberry \& Wilson, 2009). Pendidikan akan meningkatkan kemampuan seseorang untuk mengembangkan cara berpikir.

Ibu dengan primipara belum mempunyai pengalaman tentang perawatan kehamilan dan persalinan. Peran sebagai orang tua di usia muda akan memengaruhi kepercayaan diri terkait belum adanya pengalaman melahirkan (Kuo, 2012). Kondisi psikologis seorang ibu dapat terganggu karena adanya kecemasan dan tanggung jawab baru sebagai seorang ibu. Hal ini berhubungan dengan kesiapan ibu sebelum menerima peran sebagai orang tua.

Menurut Bandura (2005) pengalaman pribadi yang dimiliki oleh individu sebelumnya dapat membantu individu mengembangkan efikasi dirinya secara efektif terhadap keberhasilan melewati masa sulit, seperti kelahiran BBLR. Pengalaman pribadi seseorang membentuk sebuah harapan dan keyakinan diri bahwa individu akan berhasil dan sukses melewati sulit pada keadaan yang sama maupun berbeda dengan upaya yang telah dilakukan

\section{Dukungan Keluarga Pada Ibu Muda Dalam Melakukan PMK}

Ibu yang mempunyai BBLR mendapatkan dukungan untuk melakukan PMK dari suami dan keluarga. Dukungan terbesar yang seharusnya didapatkan oleh ibu adalah dukungan suami, karena suami merupakan sumber dukungan utama ibu dalam merawat bayi. Suami berperan sebagai ayah setelah kelahiran bayinya, kasih sayang ayah meningkat saat ayah berinteraksi dengan bayi, dan meningkatkan kedekatan antara hubungan ayah dan bayi (Hawarth et al., 2011).

Salah satu cara merawat BBLR adalah dengan perawatan metode kanguru (PMK). PMK merupakan salah satu hal penting dalam pencapaian peran ibu (Mercer, 2006). Pencapaian peran ibu secara optimal dapat 
menciptakan hubungan yang positif antara ibu dan bayi. Peran ibu dapat diperoleh ketika ibu melakukan perawatan pada bayi (Cinar \& Oturk, 2014). Dukungan dari anggota keluarga lain sangat diperlukan oleh ibu untuk membantu menyelesaikan tugas-tugas rumah.

Dukungan keluarga terutama suami merupakan faktor penting keberhasilan proses pembelajaran dan kemampuan pelaksanaan PMK sehingga ibu merasa percaya diri dalam merawat bayi. Dukungan yang diberikan keluarga memberi ibu waktu yang cukup untuk meningkatkan intensitas hubungan dengan bayinya sehingga dapat meningkatkan kepercayaan diri ibu (Barkin et al., 2010).

\section{PENUTUP}

\section{Kesimpulan}

1) Karakteristik responden didapatkan bahwa dari 26 responden rerata usia ibu 22,5 dengan pendidikan tertinggi, yaitu: pendidikan dasar $65,39 \%$, (17 responden), presentasi dan sebanyak 24 responden $(92,30 \%)$ belum memiliki pengalaman melahirkan

2) Responden yang mendapatkan dukungan keluarga lebih banyak yaitu 92,30\% (24 responden) dibandingkan responden yang tidak mendapatkan dukungan keluarga

\section{Saran}

Peran perawat anak sebagai pemberi edukasi, dapat mensosialisasikan mengenai PMK kepada masyarakat dikarenakan edukasi PMK dan kemampuan pelaksanaan PMK merupakan bagian dari upaya preventif untuk mencegah terjadinya hipotermi pada BBLR. Perawat anak melalui asuhan perkembangan yang berfokus pada keluarga dapat melibatkan ibu dalam perawatan termasuk mengenalkan ibu secara dini mengenai PMK, sehingga ibu merasa siap untuk melakukan PMK ketika bayi sudah diizinkan PMK.

Melakukan kunjungan rumah pada BBLR untuk melakukan evaluasi kemampuan pelaksanaan PMK pada ibu setelah bayi keluar dari rumah sakit.

\section{DAFTAR PUSTAKA}

Ahmed, F. A., Moussa, K. M., Petterson, K. O. M., \& Asamoah, B. O. 2012. Assessing knowledge, attitude, and practice of emergency contraception: Across-sectional study among Ethiopian undergraduate female student. BMC. Public Health, 12(110), 1-9.

Badan Pusat Statistik. 2013. Survei Demografi dan Kesehatan Indonesia 2012.

Jakarta. http://chnrl.org/pelatihan-demografi/S DKI-2012.pdf. Diakses tanggal 17 Maret 2018

Bandura, A. 2005. Self efficacy mechanisms in human agency. American Psycologist, 37, 122-147.

Barkin, J. L., Wisner, K. L., Brombeger, J, T., Beach, S. R., \& Wisnewski, S. R. 2010. Assesment of functioning new mother. Journal of Women Health, 19(8), http://dx.doi.org/10.1089/jwh.2009.18 64.

Cinar, I. O., \& Ozturk, A. 2014a. The effect of planned baby care educationgiven to primiparous mothers on maternal attachment and self-confidence levels. Health Care for Women International, 35 , 320-333. http://dx.doi.org/10.1080/07399332.2 013.842240 .

Departemen Kesehatan Republik Indonesia. (2010). Pelayanan kesehatan neonatal esensial: Pedoman teknis pelayanan kesehatan dasar. Jakarta: Kementerian Kesehatan Repulik Indonesia.

Dinas Kesehatan Kabupaten Indramayu. 2016. Profil kesehatan kabupaten Indramayu.

Hawarth, A., Swain, N., \& Trehane, G. 2011. First time new zealand mothers experience of birth: Importace of relationship and support. New Zealand College of Midwives Journal, 45, 6-11.

Hockenberry, M. J., \& Wilson, D. 2009. Wong's nursing care of infant and 
children (8th ed.). St. Louis: Mosby Elsevier.

Kementerian Kesehatan Republik Indonesia. (2016). Pusat data dan informasi kementerian kesehatan RI (PUSDATIN): Situasi kesehatan reproduksi remaja. Jakarta: Pusat Data dan Informasi Kementerian Kesehatan RI.

http://www.depkes.go.id/resources/ download/pusdatin/infodatin/infodatin \%20reproduksi\%20remaja-ed.pdf. 7 April 2018.

Kementerian Kesehatan Republik Indonesia. 2014. Profil Kesehatan Indonesia Tahun 2013. Jakarta: Kementerian Kesehatan RI. http://www.depkes.go.id/resources/do wnload/pusdatin/profil-kesehatanindonesia/profil-kesehatan-indonesia2013.pdf. Diakses Taggal 20 Februari 2018

Kuo, C. P., Chuang, H., Lee, S. H., Liao, W. C., Chang, L. Y., \& Lee, M. C. 2012. Parenting confidence and needs for parents of newborns in taiwan. Iranian Journal of Pediatrics, 22(2), 177-184. https://search.proquest.com/docview/1 347455041 ? accountid $=17242$

Mercer, R. T., \& Walker, L. O. 2006. A review of nursing interventions to foster becoming a mother. Journal of
Obstetric, Gynecologic, \& Neonatal Nursing, 35, 568-582.

Mutmainah, M. 2006. Efektifitas pendidikan kesehatan pada periode awal postpartum dengan metode CPDL terhadap kemampuan ibu primipara merawat bayi di Provinsi Jambi. Depok: Tidak dipublikasikan.

Proverawati, A., \& Ismawati, C. 2010. Berat badah lahir rendah. Yogyakarta: Nuha Medika.

Santrock, J. W. 2012. Life-span development. 13th Ed. University of Texas, Dallas: Mc Grawa-Hill.

Seidman, G., Unnikrishnan, S., Kenny, E., Myslinski, S., Smith, S. C., Mulligan, B., ... Engmann. C. 2015. Barriers and enablers of kangaroo mother care practice: A systematic review. Plos One, 10(5), 120.http://dx.doi.org/10.1371/journal.p one.0125643.

Worku, B \& Kassie, A. 2005. Kangaroo mother care: A randomized controlled trial on effectiveness of early kangaroo mother care for the low birthweight infants in addis ababa, ethiopia. Journal of Tropical Pediatrics, 51(2), 93-97. http://dx.doi.org/10.1093/Tropej/Fmh 085 